\title{
NEW EDUCATION POLICY'S PRIORITIES AS A FUNCTION OF ECONOMIC DEVELOPMENT OF SERBIA ${ }^{3}$
}

\begin{abstract}
The subject of the analysis is the importance of new education policy of Republic of Serbia, as one of the key factors for economic development, whose dynamics depends on the degree of its realization and capacity of state to implement New Strategy for development of education in Serbia until 2020 (Law on government $R S, 2005)$. In long term, the biggest importances in the process have investments into human capital and education, and research and development. The goal of the paper is to demonstrate that New Strategy for development of education in Serbia until 2020. has responded to requests that educational system should correspond to needs of the economy, to establish active institutional system of linking between science and industry; and that policy of incentives should be focused towards innovation in entrepreneurial sector. The paper starts with hypothesis that level of development of the economy depends on the results of conducted reform in education system, as well as that education system of Republic of Serbia, whose standards lag behind the outstanding legislation standards of European Union, does not satisfy immediate needs of the current economic structure. Defined hypothesis is confirmed in the paper, by the use of comparative legislation analysis of educational policy in European countries and surrounding countries. Basic message of the paper is that establishment of economic development of Republic of Serbia in post-crisis period is closely linked to implementation of education policy whose priorities are given in the New Strategy for educational development in Serbia until 2020, because without reform of education system is impossible to implement structural reforms in the economy.
\end{abstract}

Key words: education, economic development, Strategy for development of education

JEL classification: K22, K23, I25, I28

\footnotetext{
1 mknezevic@kg.ac.rs

2 pveselinovic@kg.ac.rs

${ }^{3}$ The project of Faculty of philosophy in Kosovska Mitrovica, "Kosovo and Metohija between national identity and European integrations", funded by Ministry of education, science and technology development of Republic of Serbia (project number: 47023).
} 


\section{ПРИОРИТЕТИ НОВЕ ОБРАЗОВНЕ ПОЛИТИКЕ У ФУНКЦИЈИ РАЗВОЈА ПРИВРЕДЕ СРБИЈЕ}

\section{Апстракт}

Предмет анализе је значај нове образовне политике Републике Србије као једног од кљућих фактора привредног развоја чија брзина зависи од степена юене реализачије и капаџитета државе да спроведе Нову Стратегију развоја образовањ а у Србији до 2020. године (Закон о Влади РС, 2005). Дугорочно гледано, највећи значај у том прочесу имају инвестиције у хумани капитал и образовање, истражсивање и развој. Циљ рада је да укаже да је Нова Стратегија развоја образовања у Србији до 2020. године одговорила на захтеве да образовни систем буде у складу са потребама привреде, да се успостави активан инситуционални систем повезивања науке и индустрије; и да се подстицајна политика усмери ка иновацијама у предузетничком сектору. У раду се полази од хипотезе да степен развијености једне привреде зависи од резултата спроведене реформе у образовном системукао и да образовни систем Републике Србије, чији стандарди заостају за важећим стандардима у права Европске уније, не задовољавају ни непосредне потребе садашње привредне структуре. Постављена хипотеза се потврђује у раду уз коришћење упоредноправне анализе образовне политике у европским земьама и земьама из окружења. Основна порука у раду је да успостављање привредног развоја Републике Србије у посткризном периоду, је уско повезано са спровођенем образовне политике чији су приоритети дати у Новој Стратегији развоја образовања у Србији до 2020. године, јер без реформе образовног система немогуће је спровести структурне реформе у привреди.

Кључнеречи: образовање, развој привреде, Стратегија развоја образовања.

\section{Introduction}

Mixture between traditional inheritance and history records especially each of existing education systems in the world, although all of them are linked by similarity of goals and role in the society (Lukic, 2003).

No matter the specificity, education systems of countries have the subject of, or better, the goal to have the knowledge which is not divisible, but on the contrary universal and general.

Knowledge as such does neither have limits, nor memberships in international organizations and regional unions.

Such character of knowledge should define education systems towards accessibility, linkages, indivisibility, transparency as well as universality and applicability everywhere and by each member of human community.

Universities are of vital importance for social, cultural and economic development of every country, and freely speaking, entire human society.

Universities are the best in fulfilling tasks of keeping, transferring and improvement of knowledge through education and research, because of their autonomy where there are no political, ideological and corporative influences. 
Analysis of the current moment and state of educational systems and educational policies in the world, helps coming to numerous conclusions, as well as dilemmas.

Increase and popularization of higher education led to more funds from private sources, which automatically induced question of availability of tertiary education, and therefore integrity of academic work (Robinson, 2009).

In the last two decades universities in Europe became part of university education market, where due to severe competition, changes occurred. All over the world is present commercialization, privatization of universities in order to provide answers to requests of internationalized market, where education becomes part of international trade agreements.

Members of World trade organizations took over the responsibility within General Agreement on Trade of Services (GATS) to liberalize university education that is to provide access to education market for foreign legal entities and give them adequate legal position according to the principle of fair treatment (Santiago, Tremblay, Basri \& Arnal, 2008).

European policy defined clear goal of strengthening the role of universities in achieving goals of Lisbon strategy, where economic development and society were based on knowledge as the basis for European competitiveness.

Creation of education policy is always done within frameworks of existing national and historic circumstances, with defined goal: higher public funding in order to achieve wider social engagement, or privatization of funding of university education in order for individuals to have benefits, that is, decision regarding relationship between state and market towards concept of cost or investment (Turajlic, 2009).

In that relationship which depends from social tendencies and phase where the society is, various implementation models occur (Vukasovic, 2012). In some countries tendencies are such that from the need of unifying legislation and its harmonization, we enter into phase of strong education market liberalization, and latter implementation of various methods of control and surveillance.

Within European Union and its member states, higher scholarships than Serbia, Croatia and Montenegro are paid only in Netherlands, Great Britain and Latvia.

Solution is to find balance between market demands and clearly defined standards, where leading role should be played by authorized state institutions.

\section{Legislation framework for the development of university education in Republic of Serbia}

Law on higher education in Republic of Serbia is defined within established limits of education policy and newly defined reform (Law on higher education, RS, 2005).

This law defines system of higher education, conditions and manner of performing activities in higher education, funding, as well as other issues important for this activity.

Higher education operations are especially important for Republic of Serbia and they are part of European education, science and art space (Law on higher education, Article 2).

Law is based on the principle of academic freedom, autonomy; unity of education and scientific, research and artistic work; openness towards public and citizens; respect 
of humanistic and democratic values of national and European tradition and values of cultural heritage; validation of human rights and civil rights and freedom, including prohibition of all kinds of discrimination; coherence with European system of higher education and improvement of academic mobility of teachers and students; participation of students in management and decision making, especially regarding questions important for quality of lectures; equality between institutions for university education no matter of property status, or the founder; affirmation of competition of education and research services in order to increase quality and efficiency of university system; providing quality and efficiency of studies.

Goals of higher education are transferring scientific, experts and artistic knowledge and skills; development of science and improvement of artistic creations; providing scientific, skilled and artistic legacy; giving opportunities to individuals that under the same conditions gather higher education and to be educated throughout their life; significant increase in the number of inhabitants with higher education (Law on higher education, Article 3).

Republic of Serbia is a part of process for creation European university education space (Karavidic, 2005).

The main goal of current Law on higher education is providing legal frame for implementation of Bologna process, and involvement of Serbian institutions in European academic space for higher education.

Readiness for integration is appreciated through coherence between legislation, reform of studies and their completion with adequate financial infrastructure, staff, material and technical support, through the existence of practical training, mobility of students, fundamental corrections of obligatory literature, large number of students with negative influences on teaching staff regarding scientific and research operations (Karavidic, 2006).

According to Law on higher education integrative function of university is related to establishment of unified standards of operations. Integrated university, as organization of faculties, was accepted by all members of European Union, USA, Canada, Japan and New Zealand. Only Serbia as one of rare countries, besides Croatia and Bosnia and Herzegovina does not have integrated university.

The main advantage of integrated university is efficient system of university education, full network, freedom of movement of science, exchange of knowledge. The essence of integrated university is more efficient studying and serious scientific and research work, and not centralized distribution of finances.

Universities should be integrated as multidisciplinary area with numerous functions (Knezevic, 2011).

In transformation of the university big role have institutions themselves which have to recognize that it is the way to provide quality, autonomy and interdisciplinary approach (Stankovic, 2011).

Higher education in Republic of Serbia is such that is must strive towards improvement of teaching, production of qualified graduated students who are demanded workforce on the market, incentives for students' creativity, no matter the fact that our universities are not ranked high on the lists of the best world universities. 


\section{Current state of education in Republic of Serbia}

Area of Republic of Serbia, and area of Southeast Europe, is still in the process of transition, which is for many phase of transition towards economic recovery. Serbian economy today faces with reform of public sector, as well as restructuring of large economic systems which continually demonstrated huge losses, and reform of education system.

One important part of reform tasks and reform activities represents area of education.

The goal of the reform should be establishment of more competitive economy and adoption of standards and regulations of European Union legislation.

Lack of information, unclear goals of high education, and not enough attention dedicated to evaluation of outcomes of high education and generally poor economic aspects of high education are characteristics of our country.

Education system in Republic of Serbia is closed, isolated, mainly shaped by short term economic interests, reformed for the short term without considering long term consequences of such changes, which inevitably induce annulment of development mission of education.

Relationship between education and society generally, and more specifically with economy of the country was defined differently depending on wider social circumstances. As the result of process of globalization, changes in education are inevitable, because in the long term education is one of factors of key importance for creation of recovery of transition economy in the country and its faster extraction from the crisis.

Mutual dependence, causality between education and uncompetitive economy, demand detailed consideration of education as the factor of sustainable economic development in the country.

Competitiveness of the economy primarily depends on outcomes of education, in sense of shaping such innovative and creative capacities among individuals who are profiled through education and are enabled for fast adjustment to global technology development trends (Ignjatijevic, Raicevic \& Đorđevic, 2011).

On the area of entire Southeast Europe and Republic of Serbia's educational policy is not clearly enough focused on creation such human resources.

Lack of reform of education system makes impossible to have structural economic reforms. In order to respond to such requests, thorough reforms are necessary in education, whose standards lag behind European, and do not meet even immediate needs of the existing economic structure.

Education policy of Republic of Serbia does not clearly reflect goals of Lisbon strategy defined for education and training: increased quality and effectiveness, provision accessibility to all, openness for wider public.

Besides, education is not enough supported financially by the state.

In large economies of EU (Germany, France, Great Britain, Italy and Spain) expenditures for education are on average around 5,3\% of GDP, but they are much lower from OECD's recommendation of between 6 and $8 \%$ of GDP.

For most of SEE countries (Romania, Bulgaria, Serbia, Bosnia and Herzegovina, Croatia, Macedonia, Albania, Montenegro and Moldova) these expenditures are in the interval of $4-5 \%$ of GDP, and they are lower than average expenditures in EU-27, and significantly lower than OECD's recommendation of 6-8\% of GDP. 
This entire area is specific because it is incoherent, due to large differences in education. But, human development index demonstrates that SEE countries are in the group of countries with high human development index.

If we analyze value of one of more important measures which demonstrates level of development of education - expected years of schooling (population over 25 years), we can conclude that Republic of Serbia lags behind more than 2 years, comparing to some neighboring countries.

Basic problems with which is faced existing education policy are nonexistent connection between economy and research institutions, and very small funds and investments into education and training, both on basic level, as well as for education and training of adults. System of continual education is not developed, due to small scientific and research capacities and poor finances.

According to consideration of current status of education in Republic of Serbia and previously analyzed parameters and indicators of structural changes in the economy, it is clear that these were the reasons which created New Strategy for education in Serbian until 2020., which should create basis for enactment of new regulations in the field of education, as well as their further implementation.

Besides, Strategy represents basic strategic instrument for shaping the new education policy in Republic of Serbia, based on European standards and values which demand from us to create integrated university not only on the state level, but further.

Process of harmonization of requests, opposite from tendency to have closed education system in Serbia, demands incorporation into European education space.

\section{Expected results from implementation of "New Strategy for development of education in Serbia until 2020."}

When defining new education policy, the question is, whether policy is fully prepared to cover entire process, which cannot be extracted from social surrounding, with all possible changes (Enders, Jeliazkova \& Maasen, 2003).

In the context of public policy, process of creation of education policy can be organized according to generally accepted systematization through phases of: observing the problem, defining the problem, formulation of policy, implementation of policy, evaluation or finishing of the implementation of policy.

Achieving defined goals of one policy depends also on inclusion, or accepting the policy by institutions in the country. Acceptation on both sides leads to relevant justification (Bovens, 2001).

The need of Serbia to be included in European education space, as the response to impossibility to separate and link with nearby countries, focuses education policy on organized and high quality of education system, as the key condition for development of competitive Serbian economy.

Changes in high education and successful implementation of these changes are defined, as terms, through strategy for development of education.

New strategy for development of education in Serbia until 2020,, defines purpose, goals, directions, instruments and mechanisms for development of education system in Republic of Serbia during the next ten years. It takes care of the attempt to 
shape development of this system in the best manner, known to us (New Strategy for development of education in Serbia until 2020, Article 17).

Goals which should be achieved through implementation of new Strategy in education are: improvement of education system through improvement of its quality and efficiency; harmonization of education system with European tendencies in education; development of education resources at national and local level, internationalization of education with preservation of national and cultural identity.

Education system in Serbia until 2020 should respond to vital and development needs of citizens of Republic of Serbia in the best possible manner, as well as to the needs of entire society, not only through new theoretical understandings, but through gathering knowledge and abilities, development of education procedures and life-long learning.

Better quality of secondary education is guarantor for better human capital and operations which satisfy current needs with creation of new and better jobs.

Efficient education means earlier appearance on labor market.

Final outcome of quality and efficient education is ability to implement knowledge and self-employment, linking education with other systems. PhD studies should be based on researches in order to establish productive interaction between education, research and production.

Larger number of high educated staff enables better satisfying of public needs, pensions and growth of standard of living.

Key factor of sustainable development of more quality education is education of teachers and their professionalization through constant improvement through trainings, seminaries and educations.

Such vision of education can be achieved through pluralism of proprietary relationships, adoption of national standards in education, development of resources of education and centralization of education. Education system should be developed in parallel with economy, culture, science, technology development, development of public services, administration, etc.

Education system in Republic of Serbia must become attractive for international cooperation and provision of education services (especially in higher education) in immediate surroundings of Republic of Serbia, in Western Balkans and Southeast Europe.

Integrated higher education (university, vocational academies) ensures uniformity and equality in education, more efficient understanding and solving practical problems, mutual positive and productive interaction of specialized scientific disciplines and sustainability of higher education.

Investment into education together with efficient use of existing resources enables modernization of teaching through opening new laboratories, development of computer network and exchange with foreign countries, quality work space and new scientific research (Lutovac, 2009). Objective accreditation of education institutions ensures healthy competition, and transparency induces strategic relations with other systems.

Quality of education with larger coverage of population is prerequisite for sustainability of environment because communities based on knowledge and understanding that nature must be preserved, protect the nature by the use of pure technologies. 


\section{Conclusion}

Development of Republic of Serbia, until 2020 will be focused on reindustrialization, that is revitalization and technology modernization of processing industry, development of several economic activities based on intensive implementation of knowledge and development of industrial information and communication infrastructure.

Such development involves interaction with academic, research and wider education community.

Republic of Serbia today does not have needed qualification structure which satisfies demands of labor market, and the existing system will not be able to satisfy needs of labor market and future development. From these reasons are necessary root changes in education system of Republic of Serbia, whose essence should be in adjusting the system of education in order to satisfy needs of employers and significant decrease of the number of unemployed.

Improvement of education system of Republic of Serbia is possible through constant increase the quality of education system and increase of investments into education, establishing of education system according to thorough general education which provides possibilities to select the area of additional improvement and strengthening links between education institutions, research centers and economy through inducement of cooperation programs.

Such reforms cover new regulatory framework which would have the goal to adjust education profiles with needs of employers; enactment of national framework of qualifications according to needs of labor market in Republic of Serbia; development of clusters which connect private and public sector and cover group of companies, suppliers, services and related institutions (education and research institutions, institutes, faculties, schools).

It is necessary to strengthen institutional cooperation between education institutions and economy, establish new and enforce existing centers for carrier development located on education institutions, councils for reform of schedules of work at education institutions (especially faculties) where would be representatives of entrepreneurs and improve the work of National employment office, to be able to predict the needs of labor market like EU institution CEDEFOP (European Center for development of practical training).

\section{References}

Bovens, M., 't Hart, P., \& Peters, B.G. (2001). Success and Failure in Public Governance, Cheltmen: Edward Elgar Publishing, 3-29.

Enders, J., Jeliazkova, M., \& Maassen, P. (2003). Higher Education Policy Formulation and Implementation Analysis: A Framework for Case Analysis. Paper presented for the CHER 16th annual conference "Reform and Change in Higher Education: Renewed expectations and improved performance?”, Porto, 4-6 September 2003 (20 p.)

Ignjatijević, S., Raičević, V., \& Đorđević, D. (2011), Effect of technological environment effect on competition education for economic development of the Serbian. Pedagoška stvarnost, 57(5-6), 539-547. 
Karavidić, S. (2005). Financing education in Republic of Serbia. Ekonomike transformacije, 7, 17-18.

Karavidić, S. (2006). Management in education - socio-economic aspects of development and models for financing education. Institute for pedagogy and human studies, Belgrade.

Knežević, M. (2011). Problems of financing institutions for higher education, founded by Republic. In Ć. Dolićanin (Ed), Integrated university - advantages and dilemmas (pp. 67-73). Novi Pazar: State University of Novi Pazar.

Law on government, The Official Gazette of the Republic of Serbia. No 55/05, 71/05 - correction, 101/07, 65/08, 16/11, 68/12 - US and 72/12, 7/14, 44/14. According to the article 45. paragraph 1. of Law on government adopts Strategy for development of education in Serbia until 2020.

Law on higher education, The Official Gazette of the Republic of Serbia. No 76/05, 100/07, 97/08, 44/10 and 93/12)

Lukić, R. (2003). Methodology of the law. Belgrade. Justinian.

Lutovac, M.D. (2009). Expenditures for education and health care in the countries of the European Union and the Republic of Serbia. Međunarodna politika, 60(1133), 84-90.

Minsky, H. P. (2008). Stabilizing an Unstable Economy, New York: McGraw-Hill.

Radović, D., Aničić, J., \& Radović, B. (2011). Regional competitiveness in the function of economic development of Serbia. Ekonomski vidici, 16(4), 675-688.

Robinson, D. (2009). Universities are still not on the firm ground. In M.Vukasović, Ć. Dolićanin (Ed.), Funding of university education in Southeast Europe: Albania, Montenegro, Croatia, Slovenia, Serbia (pp. 7-13). Center for Education Policy: State University of Novi Pazar.

Santiago, P., Tremblay, K., Basri, E., \& Arnal, E. (2008). Tertiary Education for the Knowledge Society. Paris: OECD, 13-22.

Stanković, F. (2011). Challenges for necessary reforms of universities in Serbia. In Ć Dolićanin (Ed), Integrated university - advantages and dilemmas (pp. 19-27). Novi Pazar: State University of Novi Pazar.

Turajlić, S. (2009). From pulling the rope to examining policies. Financing university education in Southeast Europe: Albania, Montenegro, Croatia, Slovenia, Serbia, Belgrade, p. 13.

Turajlić, S. (2009). Od natezanja užeta do izučavanja politika. In M.Vukasović, Ć. Dolićanin (Ed.), Funding of university education in Southeast Europe: Albania, Montenegro, Croatia, Slovenia, Serbia (pp. 13-21). Center for Education Policy: State University of Novi Pazar.

Vukasović, P. (2012). Bologna and the European highereducation - a declaration, an area, a process. Pravni život, 1, 239 -265.

http://www.kg.ac.rs/doc/strategija_obrazovanja_do_2020.pdf (site visited: 14 . 2.2015.) 